\title{
Życie jako sposób istnienia materii - Teoria jestestw organicznych Jędrzeja Śniadeckiego
}

\section{Aniela Zubek ${ }^{1}$}

\section{Jakub Barciszewski ${ }^{1}$}

\section{Agnieszka Belter ${ }^{1}$}

\section{Jan Barciszewski ${ }^{1,2, \varpi}$}

${ }^{1}$ Instytut Chemii Bioorganicznej Polskiej Akademii Nauk, Poznań

${ }^{2}$ Centrum NanoBiomedyczne Uniwersytetu

im. Adama Mickiewicza w Poznaniu

$\square^{\square}$ Instytut Chemii Bioorganicznej Polskie Akademii Nauk, ul. Noskowskiego 12, 61704 Poznań; tel.: (61) 85285 03, e-mail: Jan. Barciszewski@ibch.poznan.pl

Artykuł otrzymano 17 października 2018 r. Artykuł zaakceptowano 10 stycznia 2019 r.

https://doi.org/10.18388/pb.2019_256

Słowa kluczowe: Jędrzej Śniadecki, epigeneza, czym jest życie, Teoria jestestw organicznych

\section{STRESZCZENIE}

W2018 roku świętujemy 250. rocznicę narodzin badacza z czasów oświecenia, Jędrzeja Śniadeckiego. Praca ma na celu przybliżyć wage jego dokonań dla rozwoju nauk przyrodniczych oraz aktualność myśli zawartych $\mathrm{w}$ dziełach jego autorstwa. Jędrzej Śniadecki kształcił się na jednych z największych uczelni Starego Kontynentu, zapoznając się z myślami znakomitych badaczy oświecenia. Owoce zawartych kontaktów i zdobytych doświadczeń możemy dostrzec na kartach dzieł Śniadeckiego. Został zapamiętany jako reformator szkolnictwa wyższego, twórca podwalin polskiej biochemii, antropologii oraz patologii. Zasłynął jako autor terminologii i języka chemicznego. Jego największym dziełem jest „Teoria jestestw organicznych", będąca próbą odpowiedzi na nurtujące naukowców i filozofów pytanie, "czym jest życie?", wprowadzająca nową definicję życia opartą na terminie "siły organicznej". Niniejsza praca ukazuje znaczenie myśli Jędrzeja Śniadeckiego w kontekście czasów, w których żył, jak również późniejszego rozwoju nauk przyrodniczych. Tezy, które odnajdujemy $w$ dziele Śniadeckiego niejednokrotnie wyprzedzały myśl kolejnych lat, co czyni je jak i ich autora wartymi pamięci.

\section{WPROWADZENIE}

Wyjątkowość jaką odznacza się rok 2018 dla świata nauki wynika między innymi z jubileuszu 250. urodzin Jędrzeja Śniadeckiego. W niniejszej pracy chcemy pokazać wielkość myśli i aktualność jego dokonań, które wydawały się być przełomowe w naukach przyrodniczych.

Urodzony 30 listopada 1768 roku w Rydlewie niedaleko Żnina, leżącego 70 km od Poznania, zmarł 12 maja (30 kwietnia według kalendarza juliańskiego obowiązującego wówczas na tych terenach) 1838 roku Wilnie. Został pochowany na oddalonym o $50 \mathrm{~km}$ cmentarzu, wsi Horodniki niedaleko Bołtupia, na terenie obecnej Białorusi.

Na wybór drogi życiowej Jędrzeja Śniadeckiego ogromny wpływ miał jego starszy brat Jan Śniadecki, wówczas nauczyciel w Akademii Krakowskiej i współpracownik Hugo Kołłątaja w Komisji Edukacji Narodowej w Krakowie [1]. Jędrzej rozpoczął naukę na Akademii Krakowskiej a po jej ukończeniu udał się do Włoch, gdzie kontynuował naukę na Uniwersytecie w Pawi (Ryc. 1). W czasie studiów poznał wielu wybitnych badaczy, przedstawicieli medycyny oraz przyrodników, m.in. Luigi Galvani, Lazzaro Spallazani (dowodzący, że istota żywa może powstać jedynie z istoty żywej) czy Alessandro Volta. W czasie studiów Jędrzej Śniadecki stał się entuzjastą i promotorem teorii Browna na temat życia i śmierci oraz chorób i ich leczenia. Po ukończeniu studiów w Pawi, Śniadecki rozważał kontynuację nauki w Paryżu jednak plany pokrzyżowała mu Rewolucja Francuska i śmierć Lavoisiera. Ostatecznie Sniadecki udał się do Szkocji. W Edynburgu pracował w laboratorium Josepha Blacka, odkrywcy drugiego znanego wówczas gazu - dwutlenku węgla. Tam też powstała pierwsza koncepcja "Teorii jestestw organicznych”. Po dwóch latach oczekiwań upływających na kształceniu w Wiedniu i pracy jako lekarz rodzinny na Wołyniu, otrzymał stanowisko profesora chemii i farmacji w Szkole Głównej Wielkiego Księstwa Litewskiego (później Uniwersytet Wileński) .

W późniejszym okresie związany był również z Akademią Medyczno-Chirurgiczną w Wilnie. Należał do Towarzystwa Warszawskiego Przyjaciół Nauk i przez 30 lat pełnił stanowisko prezesa Wileńskiego Towarzystwa Lekarskiego, które przetrwało 135 lat, aż do II wojny światowej. Wśród wielkich uczniów profesora możemy wymienić Adama Mickiewicza, Jana Wolfganga, Ignacego Fonberga, Ignacego Domeyko, Józefa Mianowskiego czy Michała Oczapowskiego. Jeszcze za życia Jędrzeja Śniadeckiego powstał wiersz „Cztery toasty pewnego chemika na cześć istot promienistych", autorstwa Adama Mickiewicza, uwiedzionego sposobem prowadzenia wykładów przez profesora. 




Rycina 1. Droga jaką przebył Jędrzej Śniadecki od Rydlewa do Bołtupiów. Linią przerywaną zaznaczona jest planowana podróż do Paryża, która nie odbyła się ze względu na panującą tam sytuację.

stworzenie podwalin rozwoju polskiej antropologii i patofizjologii [3]. leżą:

Do głównych dzieł Śniadeckiego na-

- Teoria Jestestw Organicznych

- Początki chemii

- O fizycznym wychowaniu dzieci

- O rozpuszczalnikach

- O meteorycznym żelazie Rzeczyckim

- O niepewności zdań i nauk na doświadczeniu fundowanych

\section{CZY ROK 1804 \\ ZREWOLUCJONIZOWAE ŚWIAT \\ BIOLOGII? ZNACZENIE DLA ROZWOJU BIOCHEMII}

"Teoria jestestw organicznych" opublikowana w Warszawie w 1804 roku stała się inspiracją i przedmiotem analiz z punktu widzenia wielu dziedzin nauki, od biologii, przez fizjologię, patofizjologię, filozofię0, po ewolucjonizm (Ryc. 2). Najwybitniejsze dzieło Śniadeckiego tłumaczone było jeszcze za jego życia na język niemiecki (1810 i 1821) oraz francuski (1823). Chwila ta była przełomem inicjującym dalszy rozwój nauk przyrodniczych. W przedmowie autor zapo-

\section{NOWA ERA W POLSKIEJ EDUKACJI}

Po dwóch latach pobytu w Wilnie Jędrzej Śniadecki wydał dwutomowy podręcznik chemii $\mathrm{w}$ języku polskim pt. "Początki chemii", tworząc nową, aktualną do lat 70. XX wieku terminologię oraz autentyczny język chemiczny. W pracy tej odwoływał się do spuścizny Lavoisiera, zwalczając teorię flogistyczną, panującą jeszcze $w$ polskim świecie nauki [3]. Zreformował Uniwersytet Wileński. Stworzył plan organizacji klinik przyuczelnianych, apteki akademickiej oraz zaproponował stworzenie dwóch nowych uczelni wyższych, Uniwersytetu w Kijowie oraz Głównej Szkoły Lekarskiej w Krzemieńcu na Wołyniu. W 1805 roku założył „Dziennik Wileński”, popularyzujący nauki przyrodnicze wśród mieszkańców, w którym sam również zamieszczał artykuły o szerokim wachlarzu tematów. Było to jedno z pierwszych pism naukowych oraz odznaczało się wysokim poziomem merytorycznym i dużą poczytnością [2,4]. Propagował higienę i dietetykę oraz wychowanie fizyczne, co opisał w książce wydanej w tym samym roku, pt. „O fizycznym wychowaniu dzieci". Duże zaangażowanie w tej problematyce zaowocowało w 1822 roku opisaniem przełomowej na ten czas metody leczenia krzywicy u dzieci poprzez kąpiele słoneczne [5]. W pracy „O rozpuszczaniu” odżegnywał się od teorii Bertholleta o wzajemnym oddziaływaniu mas, i opowiadał się po stronie Daltona tj. stałości i wielokrotności stosunków [2].

W 1808 roku Jędrzej Śniadecki opisał nowy pierwiastek vest, którego odkrycia nie potwierdzono. Istnieją przypuszczenia, że opisany przez Clausa ruten jest tym samym pierwiastkiem co vest [2]. Śniadeckiemu przypisuje się także wiedział wydanie trzech tomów działa, z czego ukazały się jedynie dwa [6].

Niemiecki fizjolog Johannes Peter Müller mówił o „Teorii jestestw organicznych" "wspaniałe, niestety mało znane dzieło, które streszcza w sobie filozofię medycyny naukowej" i sam wykładał jego treści swym uczniom.) [6]. Hermann Ludwig Helmholtz, inny niemiecki fizjolog i fizyk nazwał ją pierwszą naukową teorią fizjologiczną medycyny [7]. Kolejne wydania były drukowane aż do 1905 roku, czyli przez 100 lat od pierwszego ukazania się „Teorii (..)” [6]. Spoglądając na spis treści obu tomów, można zauważyć obszerny zakres dyskutowanych tematów. Obserwując numerację rozdziałów widać integralność obu tomów:

\section{TOM I}

WSTĘP.

I. Ustanowienie ogólnych początków i zasad, na których Teorya Jestestw Organicznych ma się opierać.

II. Uwaga pokarmów, napoiu, i każdey w ogólności materyi, w którey życie i organizacya ma miejsce.

III. Bliższe zastanowienie się nad życiem. Oznaczenie sposobu, iakim władze zewnętrzne odżywiaią się. Siły spoczynkowe.

IV. Powinowactwa. Ich sposób okazywania się w istotach organicznych ożywionych i martwych. Potrzeba, sposób działania i wpływ ciepła na iestestwa organiczne.

V. Zagrzebanie materyi odżywney we wnętrznościach ziemi. Jey na powierzchnię powrót.

VI. Szczególnieysze zastanowienie się nad życiem roślin. Oznaczenie działaiących w nich sił życia. 

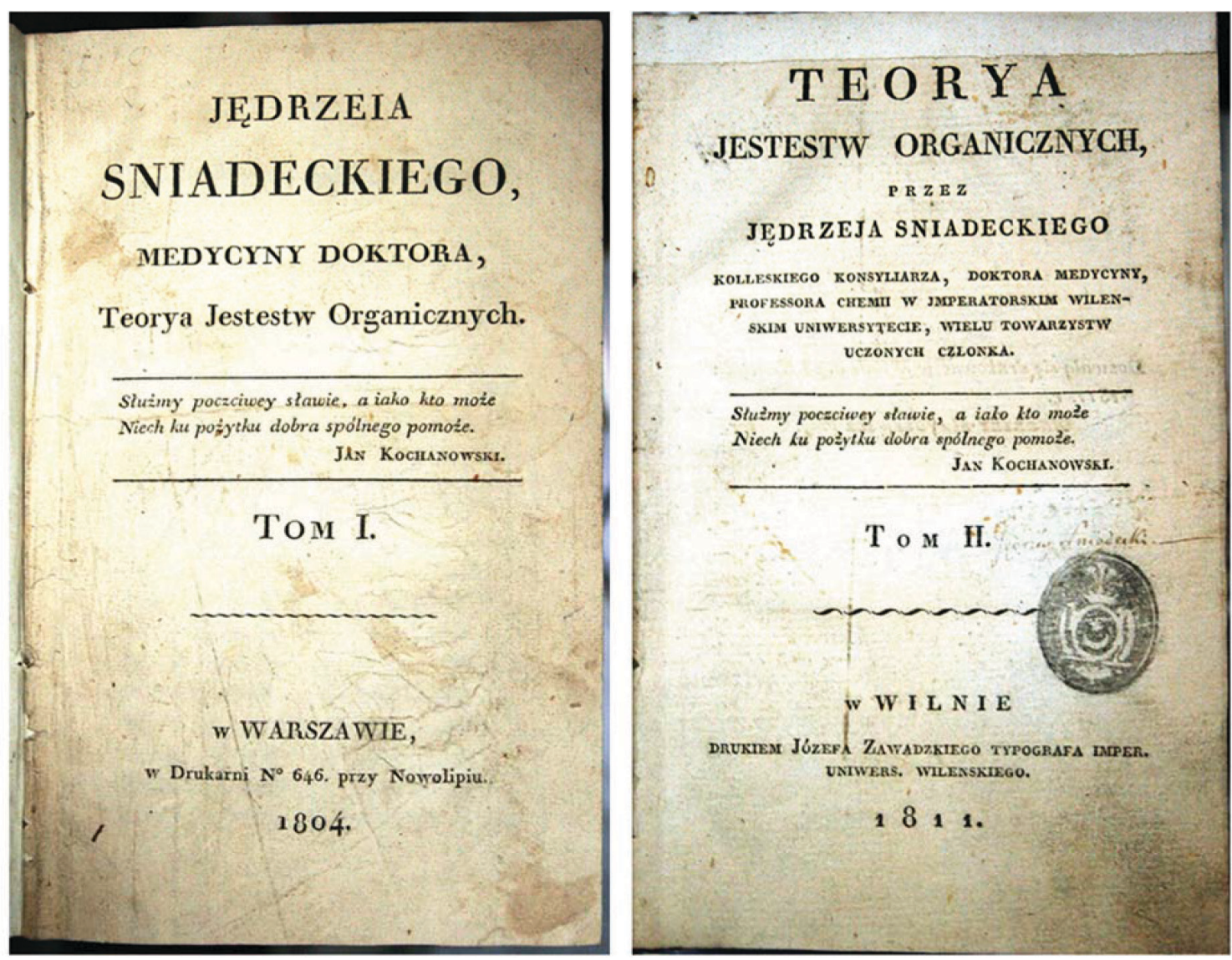

Rycina 2. Strony tytułowe Tomów I i II „Teorii jestestw organicznych”.

VII. Podobne zastanowienie się nad życiem zwierzęcém.

VIII. Odradzanie się iestestw organicznych. Rodzaie i gatunki tylko przez ciągłe formowanie individuów trwać mogą.

IX. Bieg życia iestestw organicznych. Ich wzrost, doyrzenie, schyłek i upadek.

X. Rozbiór władz zewnętrznych na gospodarstwo zwierzęce działać mogących. Ustanowienie ich stosunku i równowagi.

XI. Funkcye iestestw organicznych. Czynność poiedynczych ich narzędzi.

XII. Krótki obraz i rozbiór wyłozoney w tém pismie nauki.

XIII. Uwagi nad Teoryą Browna.

TOM II

XIV. Ogólna uwaga człowieka. Podział umieiętności wynikaiących z takowey uwagi. Różnica człowieka od innych zwierząt. Jego znaczenie.

XV. Pierwiastki i części ciała ludzkiego.

XVI. Siły życia w człowieku.

XVII. Wyobrażenie prostszych części organicznych.

XVIII. Wyobrażenie ogólnych rozcieków organicznych.

XIX. Istoty zewnętrzne odżywiające człowieka.

XX. Szereg odmian i wyrobień, którym podpadają pokarmy.

XXI. Dalsze przyswoienie pokarmów, wyrobienie krwi.

XXII. Wyrobienie krwi arteryalnéy. Płuca. Oddychanie
XXIII. Dalszy obrót krwi. Przemiana arteryalnéy w żylną. Ciepło źwierzęce.

XXIV. Przyswoienie krwi. Wyrobienie części stałych czyli karmienie.

XXV. Sekrecye.

XXVI. Soki źwierzęce służące do trawienia.

XXVII. Wyrabianie tłusczu źwierzęcego. Otyłość.

XXVIII. Odchody źwierzęce i ich wyrobienie.

XXIX. Wypadki niektóre z poprzedzaiącéj nauki.

XXX. Życie nerwów i zawisłe od niego obiawienia.

XXXI. Działanie woli. Poruszenia dowolne mięs.

XXXII. Uwagi nad teoryą działania nerwów.

XXXIII. Zwyczaj, pamięć, nauka, czucie samego siebie.

XXXIV. Sen i czuwanie.

XXXV. Krótkie zastanowienie się nad związkiém rozmaitych organów składających człowieka.

XXXVI. Różnica ludzi zależąca od klimatu.

XXXVII. Różnice pierwiastkowego ukształcenia, czyli rodzaie ludzi.

XXXVIII. Różnice ludzi co do temperamentu.

XXXIX. Różnice ludzi zależące od wieku.

XL. Różnice zależne od płci.

XLI. Różnice ludzi wynikaiące ze związków towarzyskich.

„Teoria jestestw organicznych" była pierwszą próbą stworzenia ogólnobiologicznych teorii bazującej na aktualnej wówczas wiedzy fizycznej i chemicznej. Widoczna była spójność poglądów przyrodniczych Jędrzeja Śniadeckiego z 


\section{JĘDRZEIA SNIADECKIEGO, MEDYCYNY DOKTORA,} Teorya Jestestw Organicznych.

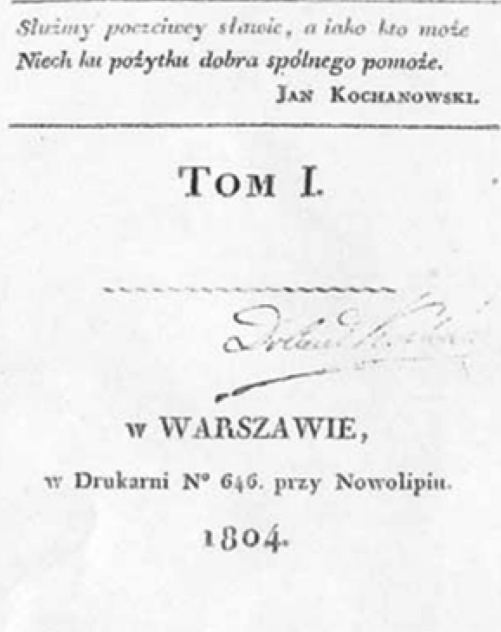

64k. - Uczeni, przywiązani $\mathrm{z}$ powolania do prac umyslowych i życia siedzącego, pielęgnuią tylko systema nerwowe $\mathrm{z}$ usczerbkiém innych systematów i wyrobién organicznych. Stąd, przy mocnieyszych wladzach umysłu, maią znaezną latwość i sklonność do wszystkich poruszeń nerwowych, a zatém wielką czulosć i niezmierną sposobność do uniesienia siẹ i zapaln. Przéciwnie, miessa maią słabe i nieznaczne, trawienie trudne $i$ niedoskonale $i$ inne wyrobienia organiczne dosyć słabe. Krótko mówiąc, są nayczystszym wzorém konstytucyi nerwowéy, która, ieżeli się w przyzwoitych zamyka obrebach, iest wlaściwa i potrzebna ich stanowi : lecz; ieżeli te granice chwalebnéy mierności przechodzi; przé rabia uczonych na naynieznośnieyszych, ơwszêm częstokroć szkodliwych w towarzystwie lülai, daiz̨c nam albó nieznosnych bakatarzy i nadelych


niespokoynych $\mathrm{i}$ burzycieli publicznego porzagdku. Takie to wzory nadto wybuialego nerwowego systemata, daị nam twórców nowych sekt, systematów i przesadzonych teoryy, których do npadlego i z naywiẹkszym bronią zapalem : z tego źrzódła mamy wszelkiego rodzaiu fanatyków tak religiynych iako i politycznych, gotowych wykorzenić resztę rodzain ludzkiego.

Rycina 3. Fragment tekstu „Teorii jestestw organicznych” dotyczący uczonych.

poglądami filozoficznymi. Znane wówczas teorie związane $\mathrm{z}$ naukami ścisłymi wielokrotnie wkraczały w obszar filozofii, proponując ogólne koncepcje życia i fizjologii. Jędrzej Śniadecki odrzucał teorie mechanistyczną i witalistyczną, przedstawiając rewolucyjne spojrzenie na zjawisko życia [8].

Przełomową wydaje się być definicja życia. Była to próba odpowiedzi na pytanie nurtujące naukowców i filozofów od wieków, czym jest życie. Chociaż pełna odpowiedź nie jest znana do dziś. Bezsprzecznie dzieło Jędrzeja Śniadeckiego było krokiem milowym na tej drodze.

Poglądy swe oparł na następujących założeniach:

- Organizmy żywe wymagają ciągłej łączności z otoczeniem.

- Organizacja, uorganizowanie stanowi niezbędny warunek bytu istoty.

- Tylko materia odżywcza (niektóre rodzaje materii) mogą podtrzymać życie.

- Do podtrzymania życia potrzebna jest materia i siła organizująca, a więc życie polega na ciągłej organizacji materii odżywczej i na jej doskonaleniu się.

Siła życiotwórcza, nadana materii nieorganicznej przy pierwiastkowym przekształceniu $\mathrm{w}$ istoty żywe, jest źródłem życia i trwa nienaruszenie przechodząc z pokolenia na pokolenie [9].
Życie jest więc pewnym sposobem istnienia materii [10]. Siła organiczna organizująca i napędzająca ruch materii i życie jest niemożliwa do pojęcia przez umysł człowieka [11]. Człowiek nie jest w stanie zrozumieć istoty tej siły i wiedza ta nie jest mu niezbędna, natomiast poznanie praw, według których ta siła działa jest konieczne. Materia organiczna jak każda inna materia podlega takim samym prawom fizycznym. Nie może jednak istnieć bez kontaktu z otoczeniem i gdy raz zostanie pozbawiona tego kontaktu, a zatem i życia, do życia nie wraca, tak i materia nieorganiczna w organiczną nie może się przemienić samodzielnie [6]. Całość obiegu materii występuje $\mathrm{w}$ ciągłym ruchu związanym $\mathrm{z}$ wchłanianiem, rozwojem i wydalaniem materii. Życie składa się więc z nieustannego ruchu, wzrostu i doskonalenia [6].

Jędrzej Śniadecki wprowadził tym sposobem drugie niemniej ważne pojęcie, jakim jest przemiana materii. Jego podstawą jest teza, że wszystko, co żyje bezustannie się organizuje, a zatem „całe życie jest ciągłym i nigdy nie ustającym procesem organicznym, albo nigdy nie ustającą asymilacją". Sam autor widział w tym stwierdzeniu największą prawdę, ",do jakiej w nauce życia przyjść było można, a która nauki naszej teraźniejszej będzie zasadą" [6]. Samo pojęcie przemiany materii nie było jego udziałem, lecz wnioski jakie wysunął były już wiekopomnym odkryciem.

Bardzo interesujące wydaje się być stanowisko Jędrzeja Śniadeckiego w temacie rozwoju osobnika po zapłodnieniu. 
Trwał wówczas spór między preformulacją a epigenezą. Pojęcie preformulacji rozwinęło się w okresie odrodzenia, a ostatecznie zostało sformułowane przez Albrechta von Hallera i Charlesa Bonneta. Teoria preformulacji postulowała, że w jaju (owuloiści) lub plemniku (animalkuiści) znajdują się $\mathrm{w}$ miniaturowych rozmiarach już wszystkie tkanki, struktury i narządy, a rozwój w kierunku pełnego osobnika polega na powiększaniu się ich rozmiarów [6,8]. Za czasów Jędrzeja Śniadeckiego koncepcja preformulacji była powszechnie uznana. Przeciwne stanowisko prezentowała teoria epigenezy, postulując rozwój embrionalny jako następujące po sobie powstawanie i rozwijanie się nowych struktur i narządów zarodka [6]. Ważną rolę w zwycięstwie epigenezy odegrał Cespar Friedrich Wolff, niemiecki lekarz i fizjolog, który przy pomocy mikroskopu obserwował rozwój kurczęcia $[6,8]$. Jędrzej Śniadecki opowiedział po stronie epigenezy. Swe argumenty oparł na zjawisku przemiany materii. Zauważył, że „życie w materii ożywionej w powszechności jest ciągłą przemianą formy, w danej formie ciągłą przemianą materii". Przekonywał, że rozwój osobniczy wbrew teorii preformalistów nie jest oparty na wzroście organów mieszczących się w miniaturze już w nasieniu, lecz powstawaniu zupełnie nowych części organizmu [8]. Zauważał wówczas wpływ warunków zewnętrznych, takich jak rodzaj pokarmów, warunki klimatyczne, aktywność organizmu czy szerokość geograficzna na zmienność cech organizmów [6]. Odnosząc tę myśl do wprowadzonego przez Conrada Hal Waddingtona w 1939 roku pojęcia epigenetyki, możemy zauważyć niezwykłość poglądów Śniadeckiego jako badacza przełomu XVIII i XIX wieku.

Jędrzej Śniadecki słusznie zauważył, że zwierzęta odżywiają się innymi organizmami żywymi, ich zwłokami bądź materią z ich rozkładu, zaś rośliny pozyskują z gleby i powietrza substraty do przemiany w pożywienie na swe potrzeby, natomiast nie cała materia wchodząca w skład kuli ziemskiej może służyć jako pokarm dla istot żywych. Materię niezbędną do funkcjonowania jako pożywienie nazwał materią odżywczą. Według Śniadeckiego „udoskonalenie materii odżywczej odbywa się kolejno w szeregu odmian, doskonali się stopniowo, aż dochodzi do takiego organu, który jej dalej udoskonalić nie może i tę dopiero materię, jako będącą udziałem w życiu, organizm jako zbędną wydziela". Zauważył, że część materii niemogąca służyć jako pożywienie dla zwierząt, jest udziałem obiegu materii dzięki roślinom, które asymilują ją i dla własnego rozwoju przetwarzają. W tym odnajdował niezaprzeczalną rolę roślin w zachowaniu istnienia zwierząt przy życiu i zatem pełnym obiegu materii [6]. Dostrzegł także ważną rolę słońca w przemianie materii, na temat której pisali 40 lat później Mayer i Helmholtz [8]. Jest to jedna z oryginalniejszych jego myśli [6]. Bazując na ogromnej wiedzy chemicznej trafnie wskazał, że mimo ogromnych różnic między organizmami, wszystkie z nich składają się z tych samych pierwiastków co materia nieożywiona, a liczba tych pierwiastków jest ograniczona [6].

Jędrzej Śniadecki dyskutował w “Teorii jestestw organicznych" również o zjawiskach geologicznych jak wymywanie skał, zmiany składu powierzchniowych warstw kuli ziemskiej oraz obiegu wody w przyrodzie. Opis obiegu wody w przyrodzie, jako pierwszy cykl BGCH (biolo- giczno-geologiczno-chemiczny) był niezwykle nowatorski. Obecnie cykle BGCH są podstawowym pojęciem nauk o środowisku przyrodniczym [7]. Wypowiadał się także na temat pochodzenia złóż naturalnych [6].

Zaobserwował, że proporcja pochłanianych oraz wydalanych substancji u osoby dorosłej, nie będącej w fazie wzrostu organizmu jest bliska jedności. Może to przypominać dobrze znane pojęcie z zakresu biochemii - bilans azotowy. Sposób omawiania zagadnień związanych z przemianą materii przypomina współczesne podręczniki biochemii: "Indywidua inaczej własnego życia zachować nie mogą, jak tylko przez ciągłą odmianę materii, z której się składają". Koncepcję nieustannej odnowy składników ciała po 150 latach udowodnili Rudolph Schoetheimer i David Rittenberg [10]. Obszernie opisana jest biochemia żywienia z uwzględnieniem przyswajalności poszczególnych pokarmów oraz ich wpływu na kondycję organizmu, bazując na metodach chemii organicznej [10]. Jędrzej Śniadecki zauważył również, że woda jest niezbędna w procesie asymilacji [11]. Należy podkreślić, że Śniadecki do swych wniosków dotarł dzięki intuicji i ogromnej międzydyscyplinarnej wiedzy [10].

Zasada jedności świata roślin i zwierząt oraz teorie fizjologiczno-chemiczne wpłynęły na rozwój nauk przyrodniczych. Polska biochemia bardzo prężnie rozwijała się na tle Europy na przełomie XIX i XX wieku. Można tu wymienić takie nazwiska jak Napoleon Cybulski (odkrycie adrenaliny), Marceli Nencki (prace nad strukturą hemoglobiny), Leon Marchlewski (praca nad strukturą chlorofilu) czy Jakub Parnas (glikoliza w mięśniach). Wszystkie wymienione prace oparte były na poglądach Śniadeckiego - dynamizmie procesów chemicznych $\mathrm{w}$ ustroju oraz jedności przemian $\mathrm{w}$ przyrodzie [10].

Jędrzej Śniadecki był również dowcipnym publicystą, którego artykuły publikowane na łamach "Wiadomości Brukowych", dzięki sprawnemu pióru cieszyły się dużą poczytnością. Pismo stworzone przez „Towarzystwo Szubrawców”, którego był współzałożycielem, publikowało celne i wnikliwe artykuły nakłaniające społeczeństwo do zmiany postaw i trybu życia, w satyryczny sposób ukazując jego wady i przywary [5]. W najważniejszym dziele nie omieszkał wykorzystać ponadto możliwości, by w charakterystyczny dla siebie, moralizatorko-kąśliwy sposób przedstawić obraz świata naukowców (Ryc. 3). Szczegół ten jest wisienką na torcie, ukazującą, jak szeroki wachlarz myśli zawarł w „Teorii jestestw organicznych”.

Zrębem teorii Śniadeckiego jest „siła twórcza” organizująca składniki materii w ciała żywe, z drugiej strony ustawiczna, nieprzerwana przemiana materii. Znaczenie myśli Śniadeckiego jest niepodważalne. Należy go wymienić obok Jean Baptiste de Lamarcka jako jednego z twórców współczesnej biologii. Prawie 100 lat później podobne do Jędrzeja Śniadeckiego myśl wyrazili Fryderyk Engels i Ernest Haeckel. Uzupełnili ją jednak o wiedzę, której autor „Teorii jestestw organicznych” nie mógł mieć, mianowicie o rolę białka. Gdyby wiedział, że proces przemiany materii i życie ma swą istotę w białku, nie musiałby tworzyć pojęcia "siły organicznej". Niemniej uzyskane wnioski pozostają niedo- 
ścignionymi przez dziesięciolecia i nie można zapomnieć, że za ich sprawą ukazał z całkiem nowej perspektywę problematykę życia i stworzył jednolitą i harmonijną teorię fizjologii życia [11].

\section{PODSUMOWANIE}

Bez wątpienia rola myśli zawartych $\mathrm{w}$ "Teorii jestestw organicznych" miały niebagatelne znaczenie dla rozwoju wielu dziedzin nauk przyrodniczych. Jak staraliśmy się dowieźć, koncepcja życia zawarta w dziele Jędrzeja Śniadeckiego jest krokiem milowym w rozumieniu otaczających człowieka zjawisk. Tezy jego nowatorskiej pracy po ponad 200 latach mogą wciąż być uznane za słuszne. Jędrzej Śniadecki wyprzedzał swoimi koncepcjami lata, a nierzadko i dziesięciolecia.

W tym szczególnym roku 250-lecia urodzin Jędrzeja Śniadeckiego powstał film Emilii Sadowskiej „Jędrzej Śniadecki” oraz utwór Krzesimira Dębskiego „,Ku pamięci Jędrzeja Śniadeckiego", które uświetniły liczne uroczystości rocznicowe min. w Poznaniu, Wilnie czy Żninie. Jak powiedział Rimantas Jankauskas, prorektor Uniwersytetu Wileńskiego, uczelnia w tym roku dokona przekładu pracy Śniadeckiego „Teorii Jestestw Organicznych” na język litewski, dzieło zostanie opublikowane także po angielsku. W Poznaniu funkcjonuje Stowarzyszenie im. Jędrzeja Śniadeckiego, Karola Olszewskiego i Zygmunta Wróblewskiego działające na dwóch płaszczyznach, naukowej oraz charytatywnej.

\section{BIBLIOGRAFIA}

1. Świeżewski, 1., Jan Śniadecki. Jego życie i działalność naukowa, Petersburg, 1898.

2. Sławiński, K., Jędrzej Śniadecki - życie i dzieła, IV Zjazd Chemików Polskich, Wilno, 30 czerwca 1938

3. Giędosz, B., Zasługi Jędrzeja Śniadeckiego dla polskiej patofizjologii, Archiwum Historii Medycyny, Kraków, 1969

4. Stobiński, J., Profesor Jędrzej Śniadecki, Nasza Księgarnia, Warszawa, 1960

5. Hutnik, B., Podobiński, S., Idee, słowa, czyny : O Jędrzeja Śniadeckiego poglądach na temat kształtowania ludzkiego fizys, Prace Naukowe. Pedagogika, (8-9-10), 79-84, 1999-2000-2001

6. Fedorowicz, Z., Ewolucjonizm na Uniwersytecie Wileńskim przed Darwinem. Memorabilia Zoologica; 4, 1960

7. Wacławek, M., Wacławek, W., Jędrzej Śniadecki i jego wkład w rozwój chemii, Chemistry-Didactics-Ecology-Metrology 13, (1-2) 69-78, 2008

8. Fryckowski, E., Jędrzej Śniadecki - wybitny myśliciel polskiego oświecenia, Zeszyty Naukowe WSP Bydgoszcz, Studia z Nauk Społecznych, 10, 17-33,1993

9. Żuliński, T., Zasady teoryi jestestw organicznych Jędrzeja Śniadeckiego, oceniane ze stanowiska dzisiejszych pojęć fizyjologicznych, Poznańskie Towarzystwo Przyjaciół Nauk, Poznań, 1874

10. Ostrowski, W., Zasługi Jędrzeja Śniadeckiego dla rozwoju chemii i biochemii w Polsce, Archiwum Historii Medycyny, Kraków, 1969

11. Szyfman, L., Jędrzej Śniadecki, przyrodnik-filozof, Książka i Wiedza, Warszawa. 1960

\title{
Life as a way of the functioning of matter - Theory of organic being of Jędrzej Śniadecki
}

\author{
Aniela Zubek ${ }^{1}$, Jakub Barciszewski ${ }^{1}$, Agnieszka Belter ${ }^{1}$, Jan Barciszewski ${ }^{1,2 \square}$
}

${ }^{1}$ Institute of Bioorganic Chemistry of the Polish Academy of Sciences, Noskowskiego12, 61-704 Poznan, Poland

${ }^{2}$ NanoBioMedical Center of Adam Mickiewicz University, Poznan, Poland

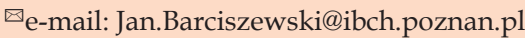

Key words: Jędrzej Śniadecki, epigenesis, what is life, Theory of organic being

\begin{abstract}
In 2018 we celebrate the 250th anniversary of the Jędrzej Śniadecki's birth. This work aims to show the importance of his thoughts for the development of natural sciences. He studied at some of the largest universities in Europe, where he met great scientists of the enlightenment. The effects can be seen in his works. He was remembered as a founder of Polish biochemistry, anthropology and pathology, also as the author of chemical terminology and language. The essence of his thoughts is "Theory of Organic being", which is an attempt to answer the question: "what is life?". Jędrzej Śniadecki introduced a new definition of life based on the term "organic power". This work shows how import are the thoughts of Jędrzej Śniadecki in the context of the times in which he lived, as well as the following development of natural sciences, what makes him and his theories worth memory.
\end{abstract}

